\title{
Heliothis species and their natural enemies, with their potential for biological control
}

\author{
C S PAWAR, V S BHATNAGAR* and D R JADHAV \\ International Crops Research Institute for the Semi-Arid Tropics (ICRISAT), Patancheru \\ 502324 , India \\ *Present address: FAO/CILSS IPM Project, BP 281, Kaolack, Senegal \\ MS received 28 April 1986
}

\begin{abstract}
Four egg and 24 larval parasitoids including one mermithid species have been identified from Heliothis armigera collected at and around ICRISAT Center. Twenty one insect and live spider specics have been recorded as predators of Heliothis. The degree of parasitism varies according to the crop. Egg parasitism is absent on chickpea, and almost negligible on pigconpea $(0.3 \%)$. Most carly larval parasitism occurs on pearl millet $(50.7 \%)$, sorghum ( $49 \cdot 5 \%)$, and chickpea ( $31.4 \%)$, whereas late larval parasitism occurs on pigeonpea $(16.4 \%)$, and groundnut $(11.5 \%)$.

The egg parasitoids, mostly Trichogramma chilonis Ishii, and the parasitoids of small larvae, mostly Campoletis chlorideae Uchida, are the most abundant natural enemies of Heliothis in the study area.
\end{abstract}

Keywords. Helochis spp., parasituids; predators; pathogens.

\section{Introduction}

The International Workshop on Heliothis Management in 1981 held at the ICRISAT, reviewed Heliothis work and discussed the future research strategies to combat the ever increasing menacc of Heliothis in national and international agriculture (ICRISAT 1982). It was recognised that work is required on a regional basis to develop integrated pest management programs for Heliothis. At ICRISAT Center, some components of integrated pest management, particularly of $H$. armigera, are under investigation. This paper reviews the results of 11 years "of monitoring of Heliothis and the natural enemies of this genus.

\section{Heliothis species at ICRISAT Center and its environs}

Three Heliothis species-H. armigera (Hubner), H. peltigera (Schiff.) and H. assulta Guenee damage crops in India. The most important of these is $H$. armigera (Jayaraj 1981; Jadhav et al 1985). This is confirmed by 11 years light trapping data from ICRISAT Center in which $H$. armigera formed $99.2 \%$ of the catch, followed by $H$. assulta $(0 \cdot 6 \%)$ and $H$. peltigera $(0 \cdot 2 \%)$.

\section{3.; Host plants and seasonal population of $H$. armigera}

Of the 96 cultivated and 61 uncultivated plant species that have been reported to be hosts of $H$. armigera in the Indian literature, 50 cultivated and 48 uncultivated 
species have been recorded at and around ICRISAT Center (Bhatnagar and Davies 1978). This wide host range covers most crops, including the ICRISAT's mandate crop: sorghum, pearl millet, groundnut, pigeon pea and chickpea.

The trend of larval population of $H$. armigera on ICRISAT crops is shown against the ICRISAT cropping schedule in figure 1. ICRISAT crops provide food for $H$. armigera from July until April, when there is a closed season of 2 months (May-June). During the closed season H. armigera survives largely on weeds. Thus, $H$. armigera can brced throughout the year at and around ICRISAT Center (Pawar et al 1984).

$H$. armigera feeds on the foliage and flowers of groundnut; the earheads of sorghum and pearl millet; the flowers and pods of pigeonpea; and the foliage, flowers and pods of chick fea. H. armigera, multiplying on rainy season crops, appears to cxert high population pressure on postrainy season crops, principally pigeonpea and

Cereols $\square$ Groundnut $\square$ Pigeonpeo Chickpeo

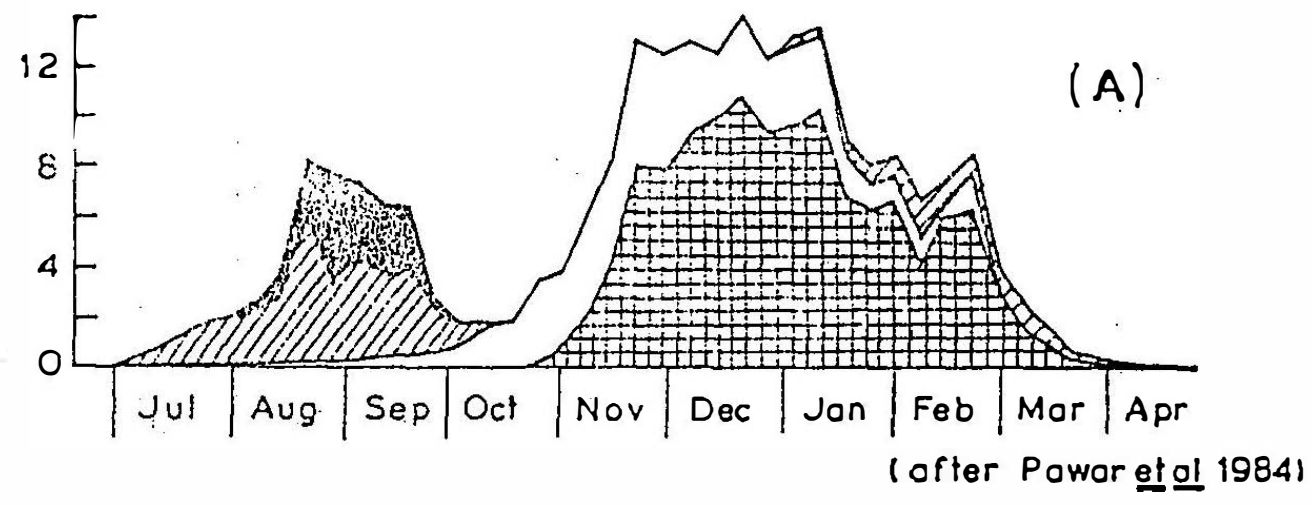

(B)

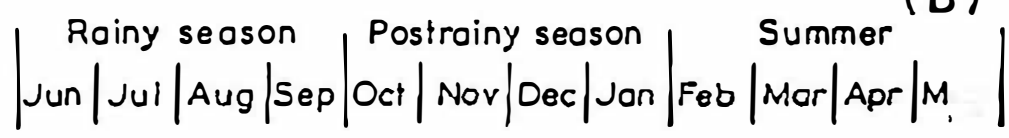

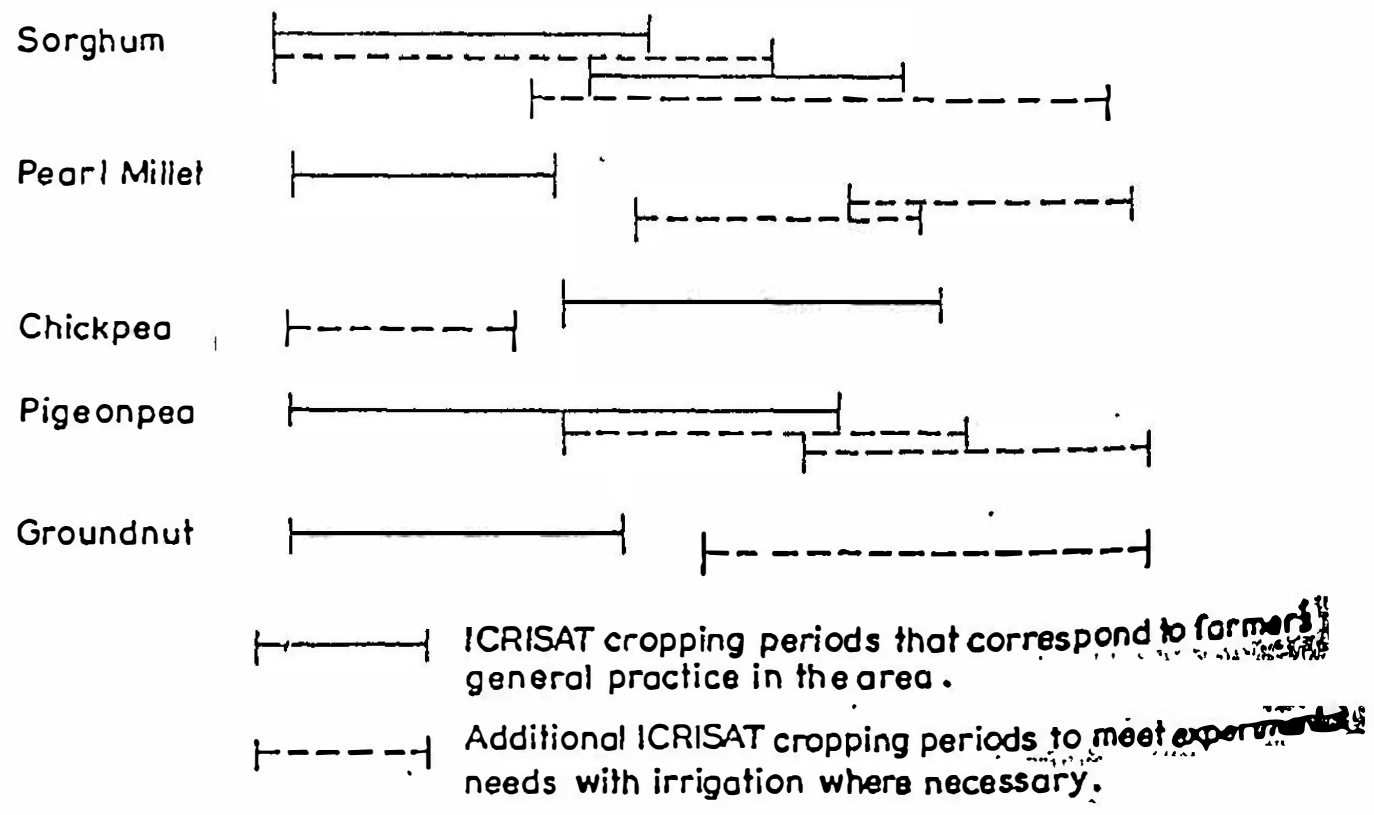

Figure 1. A. Trend of populations of $H$. armigera larvae on crops in the pestigdetents areas of ICRISAT Centre, betwcen 1979-80-1982-83. B. ICRISAT Centres coppos schedule. 
chickpea. The role of long distance migration within India and Africa in determining levels of infestation by H. armigera on different crops is now being investigated.

\section{Natural enemies of Heliothis spp.}

\subsection{Parasitoids}

The egg and larval parasitoids and their effect on Heliothis populations have been studied in relation to many plant specics. Four egg and 24 larval parasitoids including one mermithid species have becn recovered from over 80,000 eggs and 200,000 larvae of $H$. armigera collected from the ICRISAT Center farm and from farmers' fields (table 1). The parasitoids also recorded from $H$. peitigera and H. assulta are inclided in the table.

Of the egg parisitoids, Trichogramma chilonis Ishii is the most common. Hymenoptera and Dipteri hav been recovered from the larve. Most Hymenoptera emerge from $1-3$ instar larvae and from collections on coreals, wiveras most Diptera

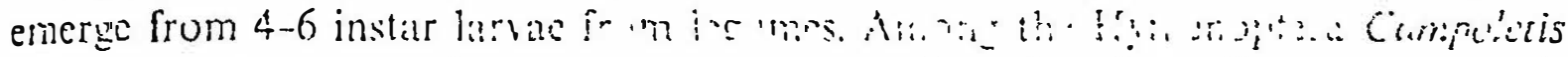

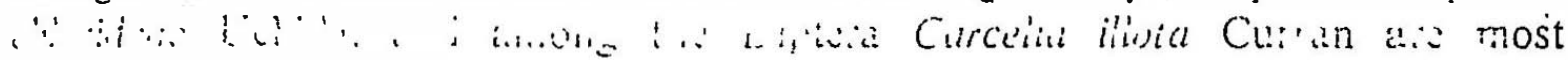
important; they ocur on many crops throughout the year. The mermithid Otomemis albicans (Sich.) is active only during the ruing susson, and only on groundnut and other short statured crops arid weeds growing on red soils (Bhatnagar el al 19\$5).

Parasitoids have their preferences for crops irrespective of their host insect. This has been observed not only with sole crops but also with intercrops. Bhatnagar et al (1979) observed that parasitoids do not transfer with H. armigera from sorghum to pigeonpea in the sorghum,'pigeonpea intercrop, but that cach crop exhibits its own parasitoid complex.

The average rates of egg and larval parasitism recorded for $H$. armigera over the past eight jears on ICRISAT mandate crops at ICRISAT Center are given in table 2. Eg mortalitics of up to $33.2 \%$ on sorghum, $10.5 \%$ on pearl millet, $14.8 \%$ on groundnut, $0.3 \%$ on pigconpea, have been recorded. On chickpea, no egg parasitism hals ever becn recorded.

Most early larval parasitism uccurs on pearl millet $(50 \cdot 7 \%)$, sorghum $(49 \cdot 5 \%)$, and chickpea (31.9\%), whercas late larval parasilism occurs chielly on pigeonpea $(16.4 \%)$ and groundnut (11.5\%). Among larval parasitoids, $C$. chlorideae contributes predominantly to the mortality of $1-3$ instar and $C$. illota much to the mortality of 46 instar larvae on all crops except groundnut, where, besides these parasitoids, the mermithid $O$. albicans is an equally or more important parasitoid (Bhatnagar et al 1985). Although, as a foliage feeder, $H$. armigera causes little or no yield loss in groundnut, the crop may act as an important reservoir for Heliothis populations when other hosts are not available or attractive.

The overall rates of egg and larval parasitism of Heliothis at ICRISAT Center by month, irrespcctive of plant species, are given in figure 2. In general, higher rates of parasitism were recorded during the rainy season when $H$. armigera is largely on groundnut, sorghum and pearl millet, whereas lower rates of parasitism were recorded during the postrainy season when Feliothis is largely on pigeonpea and chickpea. 
Table 1. Parasitoids recovered from Heliothis spp. in Andhra Pradesh Maharashtra and Karnataka 1977-1985.

\begin{tabular}{|c|c|c|c|}
\hline \multirow[b]{2}{*}{ Spccics } & \multicolumn{3}{|c|}{ Recovcred from } \\
\hline & 11. armigera & H. peltigera & H. assulta \\
\hline \multicolumn{4}{|l|}{ Insccts } \\
\hline \multicolumn{4}{|l|}{ Diplera } \\
\hline \multicolumn{4}{|l|}{ Tachinidac } \\
\hline Carcelaa mota Currand & $\sqrt{ }$ & $\sqrt{ }$ & $\sqrt{ }$ \\
\hline Exorista vamhaspis Wiadr & $\sqrt{ }$ & & \\
\hline Gonophlthulmus halli Mcsd & $\sqrt{ }$ & $\sqrt{ }$ & $\sqrt{ }$ \\
\hline Palchomisa laxa Currane & $\sqrt{ }$ & & \\
\hline Palevorista solenm, Walhere & $\sqrt{ }$ & & $\sqrt{ }$ \\
\hline Palevomstasp.e & $\sqrt{ }$ & $\sqrt{ }$ & \\
\hline Sturmulussis merems Tnss & $\sqrt{ }$ & $\sqrt{ }$ & \\
\hline \multicolumn{4}{|l|}{ Himenoptera } \\
\hline \multicolumn{4}{|l|}{ Bethylidac } \\
\hline Gonu=us sps & $v^{\prime}$ & & \\
\hline \multicolumn{4}{|l|}{ Braconddac } \\
\hline \multicolumn{4}{|l|}{ Apameliss sp. } \\
\hline \multicolumn{4}{|l|}{ Blacoll sp.' } \\
\hline \multicolumn{4}{|l|}{ Chadrmus sp" } \\
\hline \multicolumn{4}{|l|}{ Afrerorhetemus } \\
\hline cmumac ulutuls Canicron ${ }^{b}$ & $\sqrt{ }$ & $\sqrt{ }$ & $\sqrt{ }$ \\
\hline Rogacsss' & $\sqrt{ }$ & & \\
\hline \multicolumn{4}{|l|}{$\begin{array}{l}\text { Roggas sp } \\
\text { Ichneumonidac }\end{array}$} \\
\hline \multicolumn{4}{|l|}{ Burk hnciumon sp.d } \\
\hline \multicolumn{4}{|l|}{ Campoletis chlon ideae Uchadac } \\
\hline \multicolumn{4}{|l|}{ Disophly s" } \\
\hline \multicolumn{4}{|l|}{ Encospilus sp. nr. } \\
\hline \multicolumn{4}{|l|}{$\begin{array}{l}\text { shmhemm Uchidas } \\
\text { Errhonus argenteopilosus }\end{array}$} \\
\hline Camerons & $\sqrt{ }$ & $\sqrt{ }$ & \\
\hline \multirow{2}{*}{\multicolumn{4}{|c|}{ 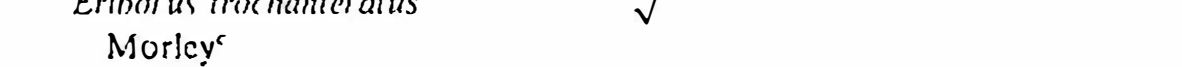 }} \\
\hline & & & \\
\hline \multicolumn{4}{|l|}{ Ichnetumom sp. } \\
\hline \multicolumn{4}{|l|}{ Metoptus rufiss Cam.c } \\
\hline \multicolumn{4}{|l|}{ Temelucha sp.' } \\
\hline \multicolumn{4}{|l|}{$\begin{array}{l}\text { Xanthopimpla stemmalor } \\
\text { Thun." }\end{array}$} \\
\hline \multicolumn{4}{|l|}{ Trichogrammaludac } \\
\hline Trichogramma chilonis Ishii ${ }^{a}$ & $\sqrt{ }$ & $\sqrt{ }$ & \\
\hline Trichogrumma sp. & $\sqrt{ }$ & & \\
\hline Trichoyrammatotdea sp." & $\sqrt{ }$ & & \\
\hline $\begin{array}{l}\text { Trichociammatosdea bactrae } \\
\text { sp. fumata Nagaraja" }\end{array}$ & $\sqrt{ }$ & & \\
\hline Mermithud & & & \\
\hline Otomermis allicans (Sıcb.) & $\sqrt{ }$ & $\sqrt{ }$ & $\sqrt{ }$ \\
\hline
\end{tabular}

u.brc.d Egg. cgg-larval, larval and larval/cx-larval parasitoids respectivcly. 
Table 2 Average parasitism (\%) of $H$. armigera eggs and larvae on ICRISAT mandate crops at ICRISAT Center, 1977-1985.

\begin{tabular}{|c|c|c|c|c|c|}
\hline \multirow[b]{3}{*}{ Crops } & \multirow{3}{*}{$\begin{array}{c}\text { Egg } \\
\text { parasitısın } \\
(\%)\end{array}$} & \multicolumn{4}{|c|}{ Larval parasitism (\%) } \\
\hline & & \multicolumn{2}{|c|}{$\begin{array}{l}\text { in } 1-3 \text { instars } \\
\text { by Campoletis }\end{array}$} & \multicolumn{2}{|c|}{$\begin{array}{l}\text { in } 4-6 \text { instars } \\
\text { by Carcelia }\end{array}$} \\
\hline & & Total & Chlorideac alone & Total & Illota alone \\
\hline Sorghum & $\begin{array}{l}33 \cdot 2 \\
(23511)^{a}\end{array}$ & $\begin{array}{l}49 \cdot 5 \\
(7877)^{a}\end{array}$ & $45 \cdot 7$ & $\begin{array}{c}5.8 \\
(8537)^{a}\end{array}$ & 3.9 \\
\hline Peasl millet & $\begin{array}{c}10.5 \\
(2986)^{\circ}\end{array}$ & $\begin{array}{l}507 \\
(584)^{n}\end{array}$ & 39.9 & $\begin{array}{l}5 \cdot 1 \\
(355)^{a}\end{array}$ & $4 \cdot 8$ \\
\hline Groundnut & $\begin{array}{c}148 \\
(2778)^{a}\end{array}$ & $\begin{array}{c}14.3[7.4]^{b} \\
(3492)^{o}\end{array}$ & 65 & $\begin{array}{c}11 \cdot 5[7 \cdot 7]^{b} \\
(3230)^{a}\end{array}$ & $1 \cdot 5$ \\
\hline Pigconpea & $\begin{array}{c}0.3 \\
(21787)^{a}\end{array}$ & $\begin{array}{c}99 \\
(10354)^{a}\end{array}$ & $3 \cdot 4$ & $\begin{array}{c}16 \cdot 4 \\
(28171)^{a}\end{array}$ & $8 \cdot 1$ \\
\hline Chichpea & $\begin{array}{c}00 \\
(3700)^{a}\end{array}$ & $\begin{array}{c}319 \\
(12969)^{\circ}\end{array}$ & $31 \cdot 6$ & $\begin{array}{c}6 \cdot 1 \\
(13283)^{a}\end{array}$ & 57 \\
\hline
\end{tabular}

- Total number of collections of eggs or larvac over the ycars

"Nematcode parastism alone (\%)

$$
\begin{aligned}
& \text { Egg } \\
& ----1-3 \text { instar larvae } \\
& \ldots . . . . . .4-6 \text { instar larvae }
\end{aligned}
$$

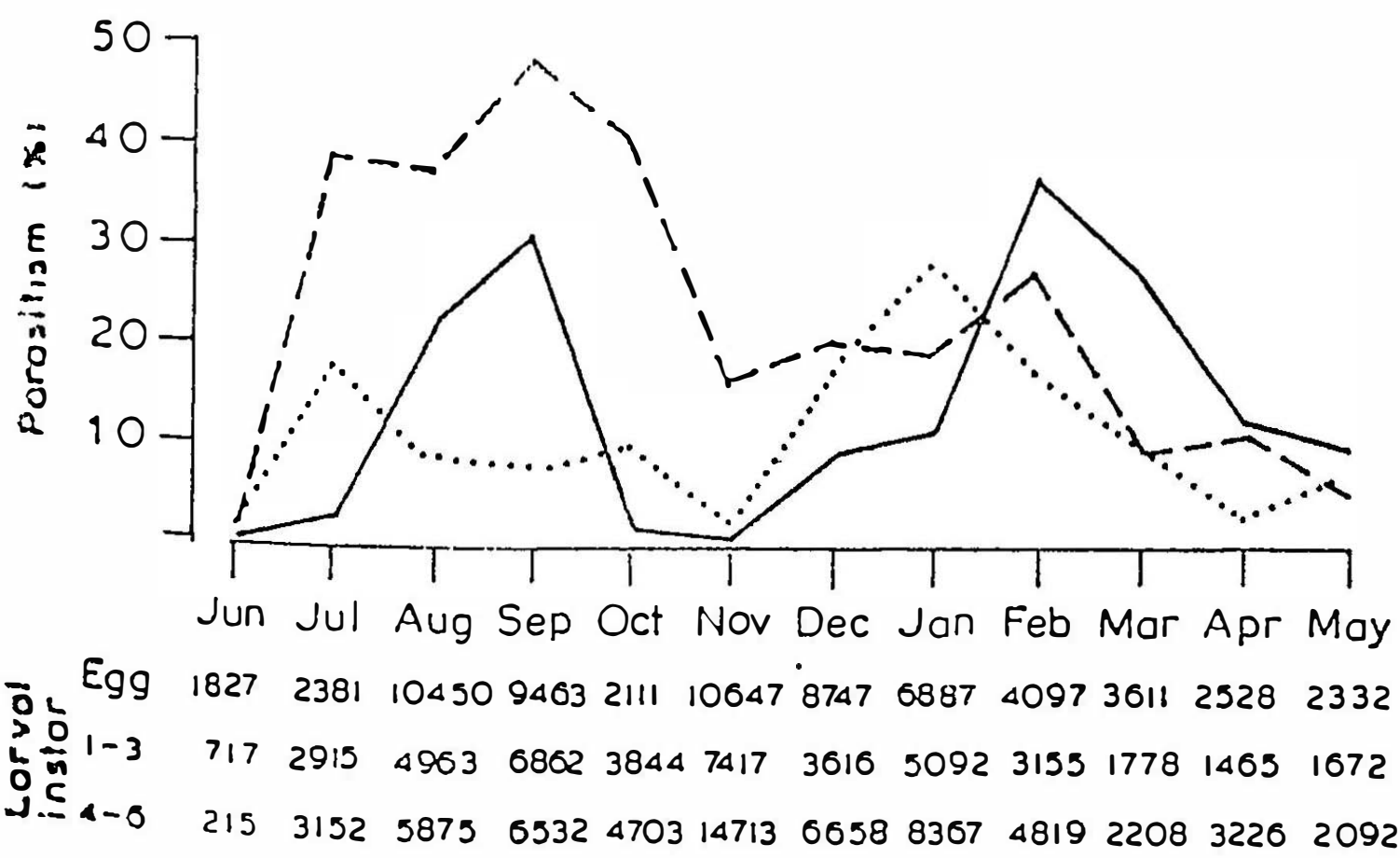

Fïgure 2. Mean egg and larta parusitusm (\%) of $H$. armgera at ICRISAT Centre, 1976-85. 


\subsection{Predators}

Although 21 insects and 5 spider species have been recorded as predators of Heliothis eggs and larvae (table 3 ) thcir effect on $H$. armigera population has not yet been quantified. Their activity, however, has been observed to differ with the crop and the soil type. We rearcd wasps, Delta spp., in a field cage and found them active when provided with a pool of water and the sucrosc, as a substitute for flowering plants (ICRISAT 1983). Birds have often been recorded feeding on larvae from crops like chickpea in areas where therc are trees to serve as roosting sites.

\subsection{Pathogens}

Whereas bacteria, fungi and viruses have sometimes causcd mortality to Heliothis larvae in the field, little is known about the quantitative impact of pathogens on field

Table 3. Arthopod prodators on 11 . ammegera (Hb.), recovered in Andhra PIadesh 1977-195.

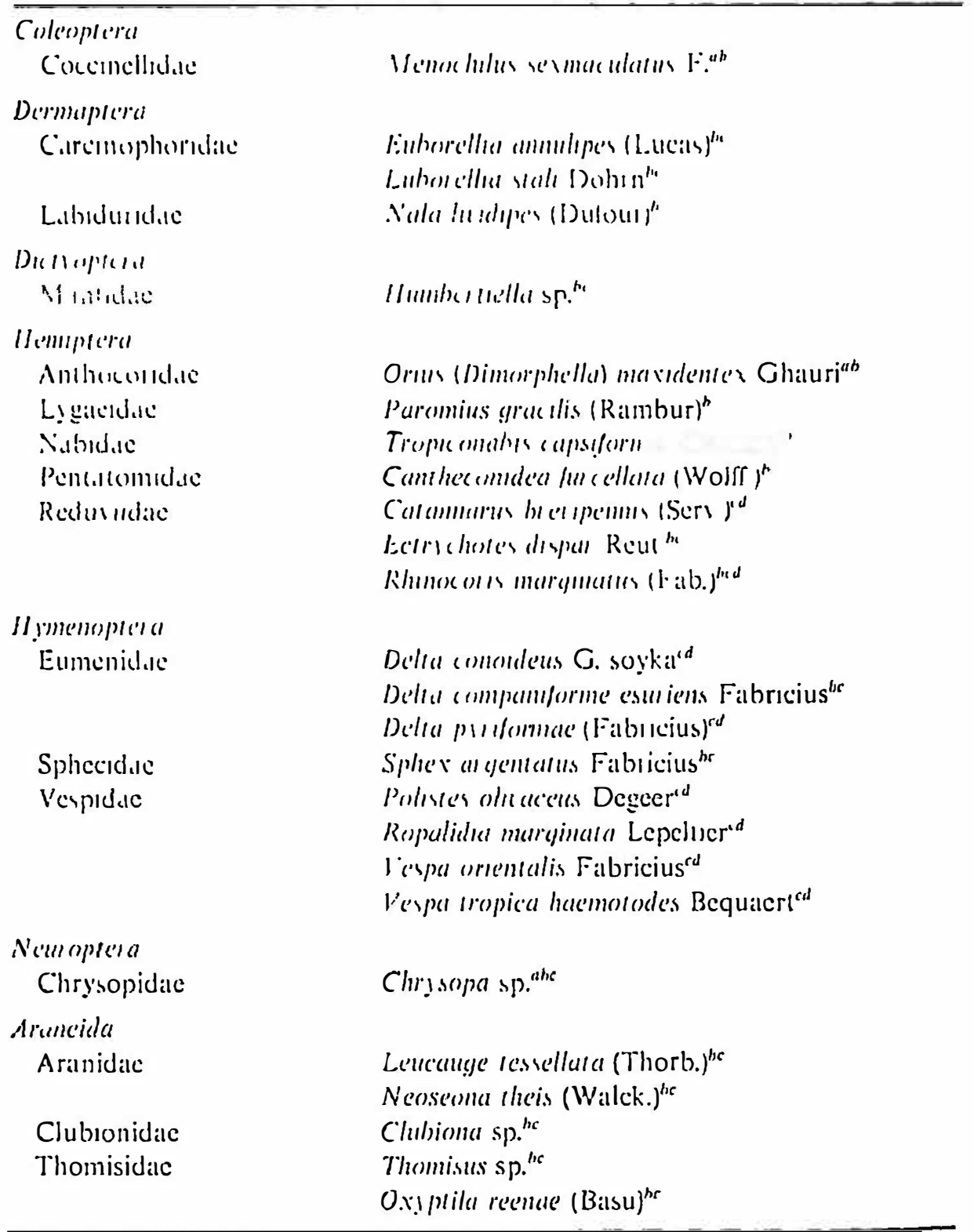

" lic. "Egge. small lall val, medium (indicalled based on obscrvalions). 
oulations. However, nuclear polyhedrosis virus (NPV) has sercrely affected a sicoratory culture of $H$. armigera (Bhatnagar et al 1982). The potential of NPV on ciickpea as a biocontrol agent has becn confirmed when artificially applied to chickpea in the field (Bhatnagar et al 1983).

\section{Scope for biological control of $H$. armigera}

In the light of the above obscrvations it could be said that, for biological control of fi. armigera at and around ICRISAT Center and in similar situations, one must aim Jt a plan to bencfit the crops of pigconpea and chickpea which are highly vulnerable 10 H. armigera, perhaps for the lack of adequate nalural control. Egg parasitism is preferathe because the insect is killed before the larva emerges to damage the crop. For example, weekly releases of the egg parasitoid, $T$. chilonis, as practiced by the sugarcane growers in Tamil Nadu, is giving good control of the internode borer, Chilo sacchariphagous indicus, of sugarcane (Solayappan 1980). However, it is known that egg parasitoids are not active on pigconpea and chickpea, so releasing them in these crops is unlikely to be effective. However, releases to increase populations in surghum. pearl millet. or groundnut to cncour age natural control before $H$. armigera :ransfers to pigconpea or chickpea may be a possibility. Finding exotic parasitoids which would also prefer $H$. armigere on pigeonpea and chichpea and breeding for crep varictics wheh are mose allative to natural cnemics could also be consitered.

Among the larval paraviobids, C. chloridecie is a potential candidate for hiological

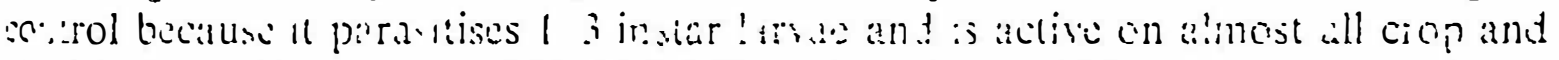

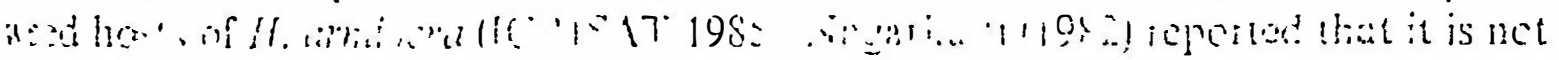

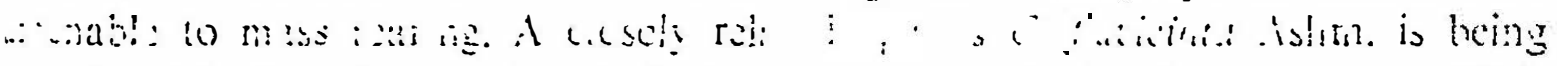

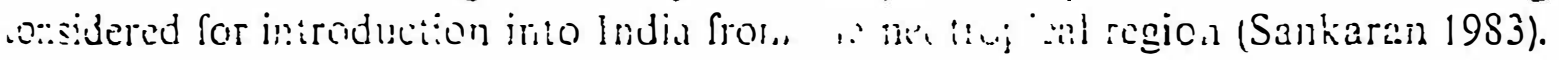

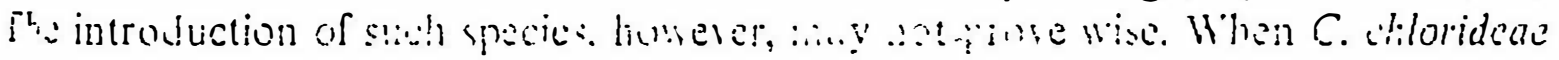

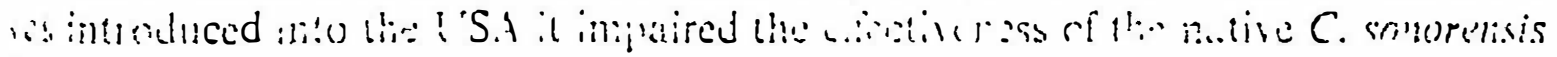

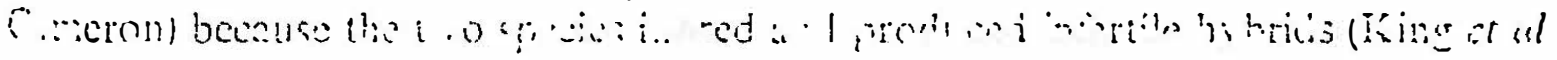
$\because \because)$

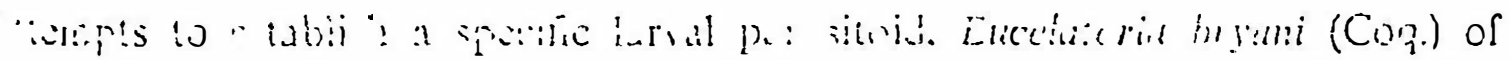
?... this imported Ho the LSA have fuid.d at ICRISAT Center (ICRISAT 1;84)

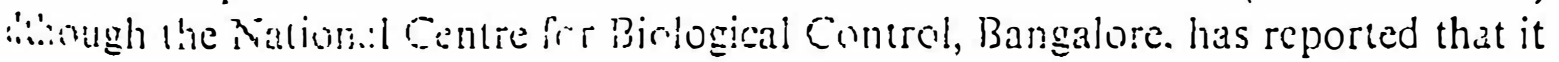

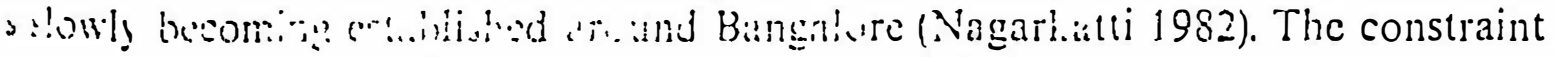

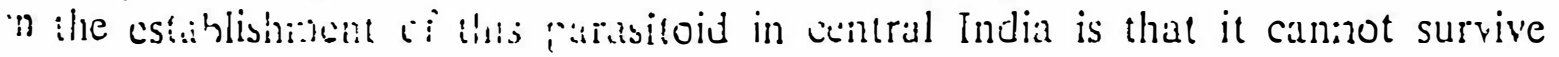
engratures glcuter than $35^{\circ} \mathrm{C}$, which are common in the summer (Bhatnagar er al [C...7). The Indian Cutncil of Agricultural Rescarch (ICAR). New Delhi is now cinsidering introducing the larral parasitoids Hyposoter didymator (Thunb.) and Apcinteles hazak Telenga from Europe where they are reported to check $H$. armigera "Win under pesticide treated conditions (S P Singh, Perl. Communication). We have to see whether these parasitoids could be established in the country.

The adoption of SNPV for the control of H. armicyera is possible. However, its use at farmers' lcvel has not yet been permitted by the Govt. of India for several reasons including the possibilitics of its harmful effects on man and animals. NPV is not effictive on all cropis; it has been reported to be effective on chickpeal (Narayanan (9) i): Santharam and Balsubramanian 1982) but not on pigeonpea (Santharam el al (1):11).

The potential uf using predators in hiological control of IIeliothis has been amply demonstrutcd elscwhere. Ridgway et al (1977) obtained good control of Heliothis 
spp. on cotton by periodic releases of eggs and larvae of Chrysopa carnea Stephein The Institute of Agricultural and Forestry Sciences in Shang-Chiu (1976) reportod $70-80 \%$ reduction in $H$. armigera larval population in cotton fields within $5-7.7$ days of the introduction of colonies of Polistes wasps. This type of augmentation of natural enemies could also be attempted here, provided that work on native predators to find their limitations in the manner done for Delta wasps at ICRISAT Center is carricd out at least for the major predators.

An important consideration for the success of biological control in an IPM Program is the use of insecticides that are relatively less toxic to parasitoids and predators than to the pests (Croft and Brown 1975). This, however, calls for the testing of available insecticides against, at least, the major parasitoids and predators as is being done in the developed countries.

\section{Acknowledgements}

The work of the pest scouts of the ICRISAT Cropping Systems Entomology team are gratefully acknowledged. The ICR ISAT's Editorial Committee, and in particular Dr J A Wightman, Principal Groundnut Entomologist, is gratefully acknowledged for critical comments while revicwing the manuscript.

\section{References}

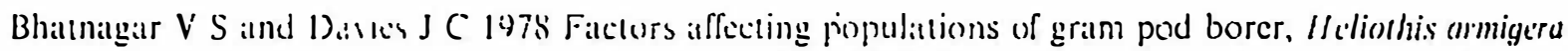
(Hubner) (Lepidoplesil. Nocluidale) in the period 1974--77 all Paltancheru. Andhra Pradesh; Bull. Encomul. 19 52-64

Bhatnagar V S and Dalvics J C 1979 Pest manalgement in intercrop subsistence farming; Proc. Im. Workishop an Inleroroppinc). ICRISAT. Palinchcru. AP. PP 249-257

Bhatnagar V S. Lalled S S. Sithanamham S. Pallatr C S and Reed W 1982 Rescarch on Helimhis al

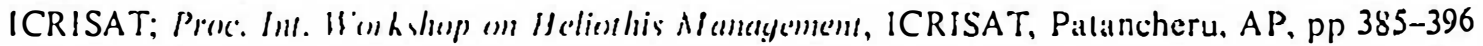

Bhatnalgar V S. Pawar C S. Jadhaly D R and Dalvics S C 1985 Mermithid nematodes as parasites of fleliothis spp. and other crop pests in Andhra Pradesh, India; Proce. Indian Acad. Sci. (Anim. Sci.) 94 509-515

Bhalmalgar V S. Sithananthatm S. Patuar C S, Jadhatv D R, Ralo V R and Reed W' 1983 Conservation and augmentation of noltural ensmies with reference 10 integralted pest management in Chickpea (Cicer

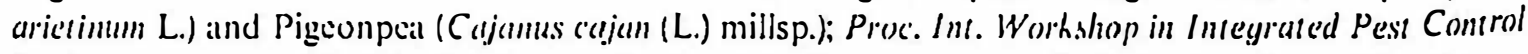
for Gruin Le'tumes, EMBRAPA Contro Nacional de Pesquisal-atroz. Goiania, Brazil, pp 157-180

Croft B A and Brown A W A 1975 Responses of arthropod nallural cnemics to insccticides; Annu. Reli. Enfomol. 20 28'5-335

ICRISAT 1982 Proc. Int. Wurkishop on Hediolhis Munugenent IC RISAT, Palancheru, AP, p 410

ICRISAT 19£3.AImur. Rup. 1982 p 265

ICRISAT 1984 Ammu. Re'p. 1983 p 165

ICRISAT $19 \$ 5$ Ammu. R(p). 1984 pp 282-283

Institutc of Agricultural and Forestry Sciences of Shang-Chiu 1976 A preliminary study on the bionomics of hunting walsps and their utilization in colton inscct control; Acta Entomol. Sinica 19 303-308

Jadhav D R, Bhatnalgar V S and Palwar C S 1985 The specics stallus of Heliothis armigera (Hub.) (Lepidoptera: Noctuidac) in Andhra Pradesh, India on the bassis of acdeagal cornutal spines; Curr. Sci. 54 239-240

Jayaraj S 1981 Biological and ecological studics of Heliothis; Proc. Int. Workshop on Meliothis Alana!yement, ICRIS.AT, Palincheru. AP. pp 17-28

King E G. Powell $\int E$ and Smith J IV 1981 Prospects for Untization of parasites and predators for management of Ilediothis sppp.; Proce. Int. Workishop on I/eliothis Manage'ment, ICRISAT, Patancheru. AP, pp $10.3-122$ 


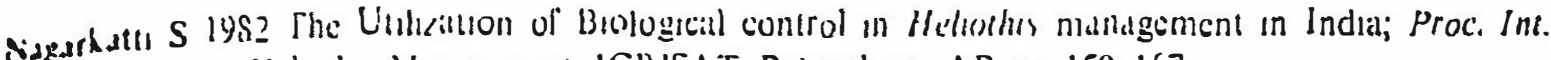

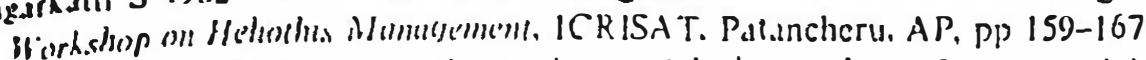

Nissusnan $K$ (197) Studies on the nuclear polyhedross virus of gram pod borer. Heliothis armigera Illubner) (Noc(uldae Lepluopicra). Ph I) thesss. Tamil Nadu Agricultural University, Coimbatore

rawas C S Srivastavad C P and Reed If 1984 Sume aspect of population dy namics of Heliothis armigera al ICRISAT Center. III Onemeal Simpostum. 21-24 Feb 1984, Universily of Kerala, Kariavaltom, Nirslit

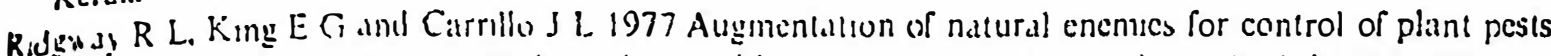

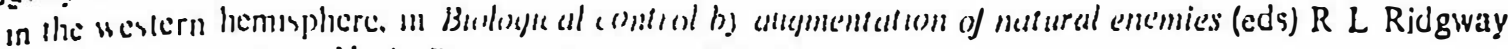
and $S$ B Vimson (ivew York. Plenum Press) pp 37y- +16

Sankiran $T$ 1983 Prospecis for natural enemy uthlsation in pest mandgement on pulses, Proc. Group

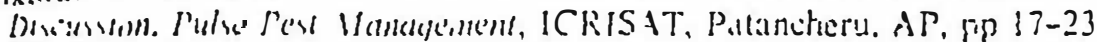

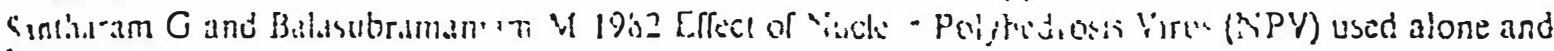

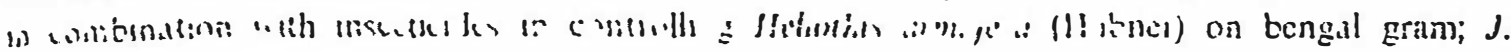

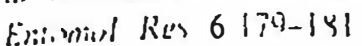

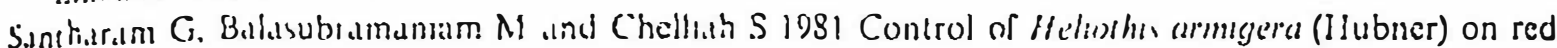

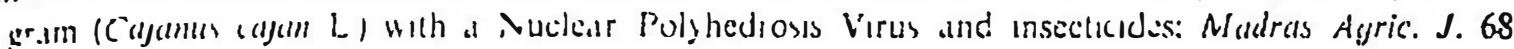
$+17+4=0$

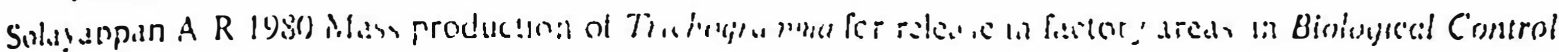

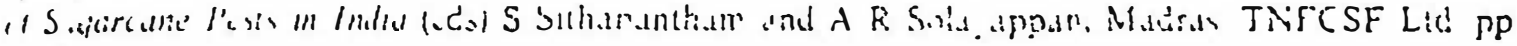
$214-35$ 